\title{
PLANKTON STRUCTURE OF SHALLOW COASTAL ZONE AT ADMIRALTY BAY, KING GEORGE ISLAND, WEST ANTARCTIC PENINSULA (WAP) DURING EARLY SUMMER/2010: PICO, ULTRA AND MICROPLANKTON AND CHLOROPHYLL BIOMASS
}

http://dx.doi.org/10.4322/apa.2014.071

José Juan Barrera-Alba1, ${ }^{1,}$ Mariana Vanzan, Márcio Murilo Barboza Tenório ${ }^{1}$, Denise Rivera Tenenbaum ${ }^{1, * \star}$

${ }^{1}$ Laboratório de Fitoplâncton Marinho, Instituto de Biologia, Universidade Federal do Rio de Janeiro - UFRJ, Av. Carlos Chagas Filho, 373, Edif. CCS, Bloco A, Sala A61, Ilha do Fundão, Cidade Universitária, CEP 20530-310, Rio de Janeiro, RJ, Brazil

*e-mail: juanalba@biologia.ufrj.br; **deniser@biologia.ufrj.br

\begin{abstract}
The phytoplankton composition and biomass are being monitored in Admiralty Bay, Antarctic Peninsula since 2002 to detect possible interannual changes on a long-term monitoring perspective. In this report, we present the results of the December 2010 survey regarding the phytoplankton size-structure and biomass. Microplankton densities were higher than those observed during the survey 2009/2010, and a dominance of diatoms, especially the centric Thalassiosira spp, over dinoflagellates was registered. Pico and ultraplankton densities $\left(\sim 10^{6}\right.$ cells $\left.L^{-1}\right)$ were similar to those registered in previous studies, and results showed that phytoplankton were dominated in density by cells $<10 \mu \mathrm{m}$. The shift in phytoplankton structure pointed out by the dominance of pico- and ultra-size cells in phytoplankton density and dominance of microphytoplankton in biomass must be confirmed by continuing the long-term monitoring program and the implementation of microvariation sampling effort to identify the factors that are actually influencing phytoplankton populations in this environment.
\end{abstract}

Keywords: microbial community, size-fraction structure, Coastal zone, PROANTAR

\section{Introduction}

The West Antarctic Peninsula (WAP) waters undergo extreme seasonal fluctuations in terms of light regime, seaice concentration and productivity (Delille, 2004). The WAP has experienced a significant rise in air temperatures during the last 50 years $\left( \pm 0.56^{\circ} \mathrm{C}\right.$ per decade; Marshall et al., 2002). The monitoring of biodiversity in shallow waters $(<30 \mathrm{~m})$ at Admiralty Bay was implemented in 2002 by PROANTAR (Brazilian Antarctic Program) during the Operation XX aiming to study the effects of environmental impacts (natural and anthropogenic) on the microplanktonic community structure, through analysis of long-term temporal series. These activities were undertaken until 2010, through four surveys, including samplings in both early and late austral summer periods (Tenenbaum et al., 2011a). Recent studies showed that in Admiralty Bay, picoplankton and ultraplankton are the dominant groups, with microplankton diatoms as the second group in abundance. Between the decades of 1990 and 2000, several studies showed a decline in diatom contribution (Kopczynska, 2008), in relation to those observed in the continental shelf region. Based on these facts since 2009 new approaches to phytoplankton monitoring have been established, including the analysis of size-fractioned pigments by spectrofluorometry, and the analysis of density and biovolume of pico- and ultraplankton by epifluorescence microscopy, and furthermore through a higher sampling frequency effort (Tenenbaum et al., 2011a). Additionally, the composition of microphytobenthos species will be carried out to study the effects of environmental changes on this community in the nearshore Antarctic ecosystem (Tenenbaum et al., 2011b). In the present study 
we show the results from early summer obtained during the OPERANTAR XXIX, December 2010.

\section{Materials and Methods}

\section{Study area}

Admiralty Bay $\left(62^{\circ} 03^{\prime}-12^{\prime} \mathrm{S}\right.$ and $\left.58^{\circ} 18^{\prime}-38^{\prime} \mathrm{W}\right)$, located at King George Island, is a deep fjord-like embayment with 500 m maximum depth at its centre (Rakusa-Suszczewski et al., 1993). The waters from the bay mix with the deep oceanic waters from Bellingshausen and Weddell Seas at its southern opening, which connects to the Bransfield Strait (RakusaSuszczewski, 1980). The maximum depth varies between $60 \mathrm{~m}$ along the shores and $500 \mathrm{~m}$ in the centre of the bay. Deep currents generated by tides, frequent upwellings, vertical mixing of the entire water column and current velocities of $30-100 \mathrm{~cm} \mathrm{~s}^{-1}$ in the $0-100 \mathrm{~m}$ surface stratum are characteristic of the bay (Rakusa-Suszczewski et al., 1993). In the context of water column production, Admiralty Bay at nearshore can be considered as Platt et al. (2003) defined as "high nutrient - low chlorophyll (HNLC): showing high inorganic dissolved nitrogen $(16.6-46.9 \mu \mathrm{M})$ and phosphate (0.2-9.9 $\mu \mathrm{M})$ concentrations, while chlorophyll levels are lower than $1.7 \mu \mathrm{g} \mathrm{L}^{-1}$ (Lange et al., 2007).

\section{Sampling}

The analysis of pico-, ultra- and microplankton and chlorophyll was performed from splits of the $5 \mathrm{~L}$ water samples collected by Van Dorn bottle from surface, middle water column and near the bottom $(\approx 30 \mathrm{~m})$ at five sites in December 2010. The Admiralty Bay location and the position of the sampling sites are shown in Figure 1.

Water temperature and salinity were analysed by the Laboratório de Química Orgânica Marinha (LabQOM),

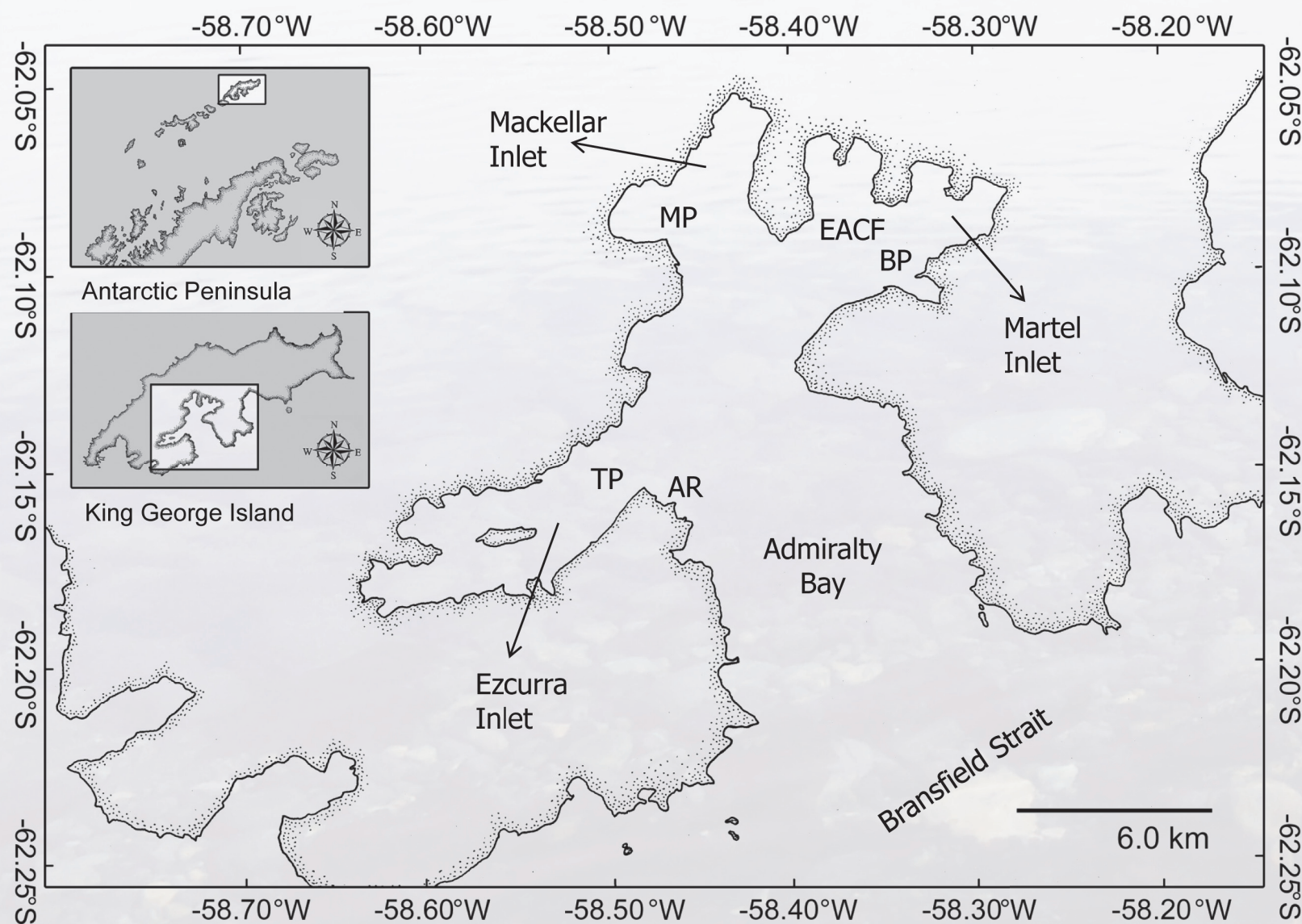

Figure 1. Study area with the position of the sampling sites: Ferraz Station (CF), Botany Point (BP), Machu Picchu (MP), Point Thomas (PT), Arctowski (AR), modified from Moura (2009). 
Instituto Oceanográfico da Universidade de São Paulo (The Marine Organic Chemistry Laboratory of the Oceanographic Institute of the University of São Paulo).

\section{Fixation and preparation of samples}

For pico- $(<2 \mu \mathrm{m})$ and ultraplankton $(2-10 \mu \mathrm{m})$, aliquots of $250 \mathrm{~mL}$ were stored in dark bottles and fixed with $0.22 \mu \mathrm{m}$-filtered glutaraldehyde ( $2 \%$ f.c.) at $4{ }^{\circ} \mathrm{C}$ until laboratory analysis. Aliquots of 5 and $30 \mathrm{~mL}$ were stained with DAPI (4'6-diamidino-2-phenylindole), $0.01 \mu \mathrm{g} \mathrm{L} \mathrm{L}^{-1}$ f.c. (Martinussen \& Thingstad, 1991), during 10 minutes and filtered respectively by $0.22 \mu \mathrm{m}$ (picoplankton) and $1.0 \mu \mathrm{m}$ (ultraplankton) polycarbonate black membrane filters (Poretics ${ }^{\oplus}$ ), and mounted on microscope slides. Slides were stored at $-20{ }^{\circ} \mathrm{C}$. Analyses were performed using an Olympus BX51 ${ }^{\circ}$ epifluorescence microscope with $1,000 \times$ magnification. The number of heterotrophs was calculated based on the total counted using DAPI (UV filter combination) minus the number of autotrophs analysed by autofluorescence (blue filter combination). For microplankton $(>10 \mu \mathrm{m}), 1 \mathrm{~L}$ were fixed with buffered formaldehyde ( $2 \%$ f.c.) and kept in the dark immediately after sampling. At the laboratory, samples were analysed using the settling technique (Utermöhl, 1958) in an Olympus IX70 ${ }^{\circ}$ inverted microscope with $400 \times$ magnification. For chlorophyll biomass, $2 \mathrm{~L}$ were filtered onto Whatman ${ }^{\circledR} \mathrm{GF} / \mathrm{F}$ for total pigments analyses, while 0.8-2 L was used for the size structure study. In the latter case, water sampled at 3 depths was fractionated by serial filtration on $10 \mu \mathrm{m}$ and $2 \mu \mathrm{m}$ polycarbonate filters and GF/F. The filters were folded, placed into a $1.2 \mathrm{~mL}$ cryotube and immediately quickfrozen in liquid nitrogen $\left(-196^{\circ} \mathrm{C}\right)$ and stored at $-80{ }^{\circ} \mathrm{C}$. Concentrations of chlorophyll $a$ (Chl.a) were assessed using a modified version of Neveux and Lantoine's (1993) method.

In order to normalize distributions and eliminate zero values, the biological data was transformed using $\log 10(x+1)$. Pearson's correlation factor was also calculated.

\section{Results}

Salinity showed little variation $(34.2 \pm 0.1)$ between sampling sites and depths, while a higher variation was observed in water temperature $\left(0.30 \pm 0.15^{\circ} \mathrm{C}\right)$. Except for $\mathrm{BP}$, water temperature decreased with depth, with values of 0.14 at surface and 0.73 near the bottom. Total chlorophyll biomass varied between 0.36 and $0.84 \mu \mathrm{g} \mathrm{L}^{-1}\left(0.54 \pm 0.12 \mu \mathrm{g} \mathrm{L^{-1 }}\right)$, with higher values registered at $\mathrm{BP}$, and the fraction $>10 \mu \mathrm{m}$ represented more than $50 \%$ (Figure $2 \mathrm{~b}$ ). An average cellular density of $1.9 \times 10^{7} \pm 0.4 \times 10^{7}$ cells $\mathrm{L}^{-1}$ was observed for total autotrophic plankton, with a maximum value of $2.2 \times 10^{7}$ cells $\mathrm{L}^{-1}$ observed at TP. The dominant fractions were pico (mean 79\%) and ultraplankton (mean 20.9\%) for all samples sites (Figure 2C). For microplankton, an average cellular density of $8.8 \times 10^{3} \pm 3 \times 10^{3}$ cells $\mathrm{L}^{-1}$ was observed, with a maximum value of $16.4 \times 10^{3}$ cells $\mathrm{L}^{-1}$ observed at BP (Figure 2d). In general, no statistically significant correlations were observed between densities and salinity, temperature or Chl.a. Only microphytoplankton showed a positive correlation with total chlorophyll biomass $(r=0.77$, $p<0.05)$. The contribution was shared by the diatoms (mean $72 \%$ ) and dinoflagellates (mean 27\%) (Figure 2d). Among centric diatoms was predominant (92\%), mainly the genera Thalassiosira. Thecate forms, especially Prorocentrum cf. antarcticum, were more abundant among dinoflagellates (56\%).

Spatially, autotrophic picoplankton densities generally decreased from the external region (AR-TP) to inner sampling stations (CF-BP). Ultraplankton contribution did not show great spatial differences. An inverse pattern was observed for microphytoplankton and diatom contribution, with higher densities observed in BP and bottom samples.

\section{Discussion}

Microplankton cellular densities and chlorophyll biomass observed in this study were low when compared to those registered for Admiralty Bay during the decades of the 1970 s, 1980s and 1990s, when densities of $10^{5}$ cells $\mathrm{L}^{-1}$ were usually registered (i.e. Kopczynska, 2008). However mean densities were six times higher than those observed by Lange et al. (2007) in a study developed during the austral summer 2002/2003, and three times higher than the means registered during the austral summer 2009/2010 (Tenenbaum et al., 2011a). The dominance of diatoms over dinoflagellates in early summer 2010 is a characteristic of microplankton community for Admiralty Bay (Lange et al., 2007; Kopczynska, 2008). But, during the study developed at 2009/2010, a decreasing $(<45 \%)$ of the contribution of diatom, especially during the late summer (Tenenbaum et al., 2011a), was observed. Water 

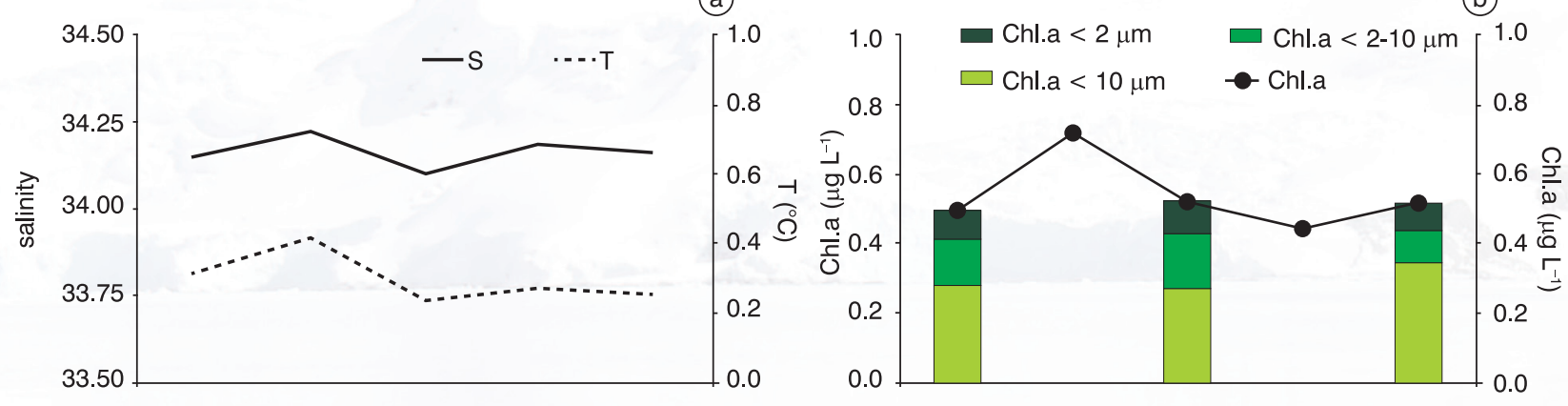

(c)
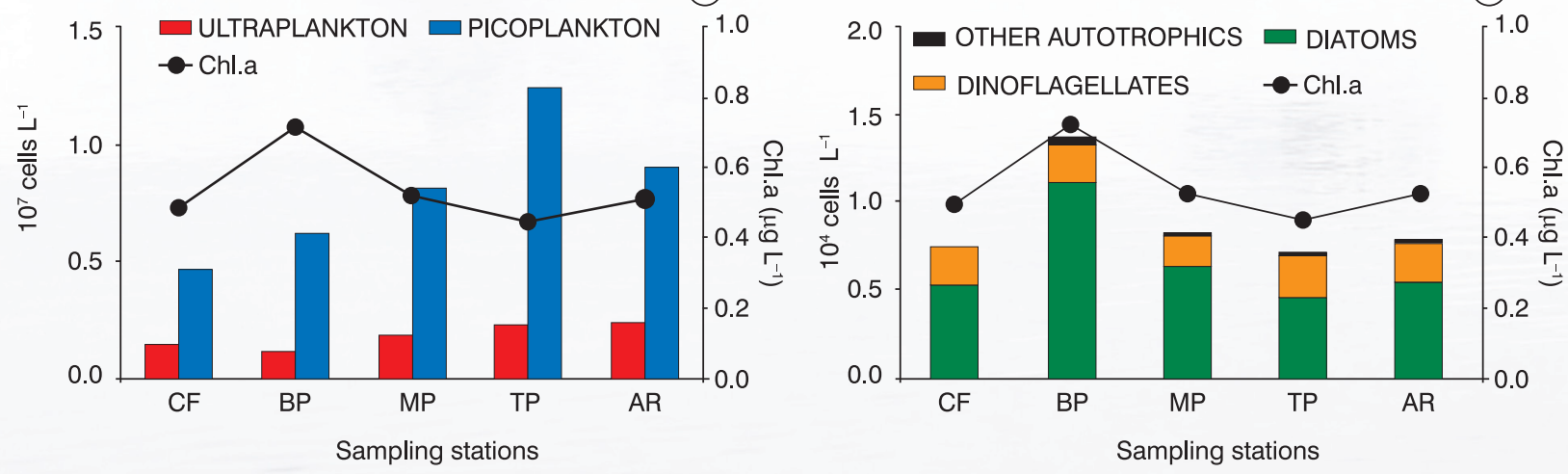

Figure 2. Variations at different sample sites at Admiralty Bay during the December 2010 survey (mean values): a) salinity and temperature; b) total and fractionate chlorophyll a concentrations; c) pico and ultraplankton densities; and d) microphytoplankton density and contribution of main groups to microphytoplankton

temperatures measured in the present study were higher than those registered for early summer in previous studies, when negative values were usually registered for December. In a different way to those related in previous studies, the centric diatoms Thalassiosira spp. dominated in early summer 2010/2011. Lange et al. (2011) described this genera as one of predominant microalgae during late summer 2002/2003, while in early summer usually pennate diatoms were dominant. Densities of pico and ultraplanktonic fraction of autotrophic community were similar $\left(\sim 10^{6}\right.$ cells $\left.\mathrm{L}^{-1}\right)$ to those observed in a previous study during the late summer 2009/2010 (Tenenbaum et al., 2011a), and were co-dominant of the phytoplankton community in Admiralty Bay. The densities of picoautotrophs were also in the same range of the values observed in other Antarctic regions (Delille et al., 2007). In the nearshore coastal waters along the Antarctic Peninsula, a recurrent shift in phytoplankton community structure, from diatoms to cryptophytes, has been documented due to high temperatures along the Peninsula increasing the extent of coastal melt-water zones promoting seasonal prevalence of cryptophytes (Moline et al., 2004). Even the dominance of pico and ultra-size cells in phytoplankton, which are not grazed efficiently by Antarctic krill, will likely cause a shift in the spatial distribution of krill and may allow also for the rapid asexual proliferation of carbon poor gelatinous zooplankton, salps in particular (Moline et al., 2004), our results show that microphytoplankton biomass $(>10 \mu \mathrm{m})$, especially diatoms, represent a high percentage of total phytoplankton biomass.

\section{Conclusion}

In the context of the regional warming trend of WAP, results of the present study showed a shift in Admiralty Bay plankton community in relation to the study developed during the austral summer 2009/2010, when contribution of diatoms decreased and low microplankton densities, dominance of dinoflagellates, mainly heterotrophs, and high contribution of autotrophs pico- and ultraplankton to total density and biomass in late summer, suggested that changes could be occurring in Admiralty Bay food web. On the other hand, the dominance of a large diatom community and the 
increasing of microphytoplankton densities, indicate that it is necessary to continue the long-term monitoring program and the implementation of microvariation sampling effort to identify the factors that are actually influencing phytoplankton populations in this environment.

\section{Acknowledgements}

This work integrates the National Institute of Science and Technology Antarctic Environmental Research (INCT-
APA) that receive scientific and financial supports of the National Council for Research and Development (CNPq ${ }^{\circ}$ 574018/2008-5) and Research Support Foundation of the State of Rio de Janeiro (FAPERJ $n^{\circ}$ E-16/170.023/2008). The authors also acknowledge the support of the Brazilian Ministries of Science, Technology and Innovation (MCTI), of Environment (MMA), Inter-Ministry Commission for Sea Resources (CIRM) and Marine Organic Chemical Laboratory of the Oceanographic Institute of Sao Paulo University (LabQOM-IOUSP).

\section{References}

Delille, D. (2004). Abundance and function of bacteria in the Southern Ocean. Cellular and Molecular Biology, 50:543-551

Delille, D.; Gleizon, F. \& Delille, B. (2007). Spatial and temporal variations of bacteria and phytoplankton in a subAntarctic coastal area (Kerguelen Archipelago). Journal of Marine Systems, 68(3-4):366-380

Kopczynska, E.E. (2008). Phytoplankton variability in Admiralty Bay, King George Island, South Shetland Islands: six years of monitoring. Polish Polar Research, 29(2):117-139.

Lange, P.K.; Tenenbaum, D.R.; Braga, E.S.B. \& Campos, L.S. (2007). Microphytoplankton assemblages in shallow waters at Admiralty Bay (King George Island, Antarctica) during the summer 2002-2003. Polar Biology, 30:1483-1492.

Marshall, G.J.; Lagun, V. \& Lachlan-Cope, T.A. (2002). Changes in Antarctic Peninsula tropospheric temperatures from 1956 to 1999: a synthesis of observations and reanalysis data. International Journal of Climatology, 22:291-310.

Martinussen, I. \& Thingstad. T.F. (1991). A simple double-staining method for enumeration of autotrophic and heterotrophic nano- and picoplankton. Marine Microbial Food Webs, 5:5-11.

Moline, M.A.; Claustre, H.; Frazer, T.K.; Schofield, O. \& Vernet, M. (2004). Alteration of the food web along the Antarctic Peninsula in response to a regional warming trend. Global Change Biology, 10:1973-1980. http://dx.doi.org/10.1111/j.13652486.2004.00825.x

Moura, R.B. (2009). Estudo taxonômico dos Holothuroidea (Echinodermata) das Ilhas Shetland do Sul e do Estreito de Bransfield, Antártica. Dissertação de Mestrado, Museu Nacional, Universidade Federal do Rio de Janeiro.

Neveux, J. \& Lantoine, F. (1993). Spectrofluorometric assay of chlorophylls and phaeopigments using the least squares approximation technique. Deep-Sea Research I, 40(9):1747-1765.

Platt, T.; Broomhead, D.S.; Sathyendranath, S.; Edwards, A.M. \& Murphy, E.J. (2003). Phytoplankton biomass and residual nitrate in the pelagic ecosystem. Proceedings of the Royal Society A, 459:1063-1073.

Rakusa-Suszczewski, S. (1980) Environmental conditions and the functioning of Admiralty Bay (South Shetland Islands) as part of the near shore Antarctic ecosystem. Polish Polar Research 1(1):11-27.

Rakusa-Suszczewski, S.; Mietus, M. \& Piasecki, J. (1993) Weather and climate. In: Rakusa-Suszczewski, S. (Ed) The maritime coastal ecosystem of Admiralty Bay. Department of Antarctic Biology, Polish Academy of Science, Warsaw.

Tenenbaum, D.R.; Barrera-Alba, J.J.; Duarte, R.D. \& Tenório, M.B. (2011a). Plankton Structure of shallow coastal zone at Admiralty Bay, King George Island, West Antarctic Peninsula (WAP): pico, nano and microplankton and chlorophyll biomass. Annual Activity Report 2010. INCT-APA, 2:108-114.

Tenenbaum, D.R., Lange, P. Barrera-Alba, J.J., Fernandes, L.F., Calixto, M. \& Garcia, V.M.T. (2011b). Plankton Structure of shallow coastal zone at Admiralty Bay, King George Island, West Antarctic Peninsula (WAP): composition of phytoplankton and influence of benthic diatoms. Annual Activity Report 2010. INCT-APA, 2121-125.

Utermöhl, H. (1958). Zur Vervollkommung der quantitativen methodik. Mitteilungen der Internationale Vereinigung für Teoretische und Angewandte Limnologie, 9:1-38. 